\title{
BACILLUS SUBTILIS NCIM2063 BATCH CULTIVATION: THE INFLUENCE OF THE SUBSTRATE CONCENTRATION AND OXYGEN TRANSFER RATE ON THE BIOMASS YIELD
}

Sandra Stamenković Stojanović1* ${ }^{*}$, Ivana Karabegović1, Vladimir Beškoski², Nada Nikolić ${ }^{1}$, Miodrag Lazić ${ }^{1}$

(ORIGINAL SCIENTIFIC PAPER) UDC 602.3:579.6

${ }^{1}$ Faculty of Technology, Leskovac, University of Niš, Serbia

${ }^{2}$ Faculty of Chemistry, Belgrade, University of Belgrade, Serbia

The objective of this study was to investigate the growth kinetics of Bacillus subtilis NCIM 2063 under different cultivation conditions. For that purpose, the growth medium was supplemented with different glucose concentrations and exposed to different values of the oxygen transfer rate (OTR). As a result, it was found that the biomass yield, the specific growth rate and generation time were affected by the change of cultivation conditions and the composition of the nutrient medium. It was confirmed that glucose is readily available substrate that enhances the cultivation in the concentration range of $5-15 \mathrm{~g} / \mathrm{L}$. Also, it was proved that the restriction of available oxygen lowers the biomass yield and slows down the replication of bacteria. The maximum biomass concentration was achieved in the medium with $10 \mathrm{~g} / \mathrm{L}$ of glucose and the OTR value of $10 \mathrm{~mol} / \mathrm{m}^{3} \mathrm{~h}$, when the specific growth rate and generation time were $0.273 \mathrm{~h}^{-1}$ and $2.54 \mathrm{~h}$, respectively. Such biomass yield can be achieved in only $24 \mathrm{~h}$, which is also economically acceptable. Therefore, the growth conditions optimized in this experiment are recommended as optimized values for further research, and can be used for economically sustainable and efficient cultivation of $B$. subtilis NCIM 2063.
Keywords: microbial biomass, Bacillus subtilis, growth kinetics

\section{Introduction}

Bacillus subtilis is aerobic, rod-shaped endosporeforming bacteria usually found in soil or water [1,2]. It has the ability to form endospores which is why it is resistant to different environmental stresses [3]. The species is also confirmed to have probiotic properties and the ability to produce various industrially important metabolites such as enzymes, antibiotics, polysaccharides and proteins [4-10].

Thanks to those abilities, the genus Bacillus is suitable for biocontrol of pathogens and has the application in many fields such as agriculture, pharmacy, medicine and many others [8,11-15].

Before starting the industrial production of $B$. subtilis and its metabolites, it is important to optimize the growth conditions and describe the bacterial growth, taking into account the influence of the important factors such as oxygen availability and substrate utilization [15]. The first step in the course of observation and description of the bacterial growth is measuring a growth curve. The increase in bacterial biomass is usually measured as a function of time, forming a growth curve of a certain shape from which specific parameters can be calculated $[16,17]$. The usual goal is to lower the duration of the lag phase, and to increase the specific growth rate which will reduce the production time and eventually the costs [18]. The value of those parameters, and therefore the shape of the growth curve, is dependent on different factors that affect the growth. In order for a microorganism to grow rapidly, it is necessary to obtain the optimum growth conditions in terms of the adequate temperature, $\mathrm{pH}$, stirring speed, the oxygen concentration and the presence of required nutrients [14,19].

Oxygen concentration is an especially important parameter when it comes to aerobic cultures. It depends on the specific growth rate and biomass concentration [20,21] and it is limited by oxygen solubility and oxygen transfer rate (OTR) [22]. Sufficient aeration is a primary precondition to successful cultivation which is why OTR needs to be monitored and adjusted during the cultivation [23]. It is also essential to optimize the growth medium, taking into account all the nutrients necessary for rapid replication of microorganisms. Glucose, which acts as a carbon source, is one of the most commonly used substrates in various cultivations. Knowing that at some concentrations the substrate inhibition could occur, it is fundamental to determine the optimum medium composition that will enhance the growth of a particular bacterium [18].

The aim of this work is to investigate the influence of different glucose quantities in the growth medium and OTR values on the growth of $B$. subtilis NCIM 2063 in terms of achieving the highest biomass yield, as well as to calculate the most important parameters that are suitable for describing the growth kinetics.

\footnotetext{
*Author address: Sandra Stamenković Stojanović, University of Nić, Faculty of Technology,

Bulevar oslobođenja 124, 16000 Leskovac, Serbia

E-mail: sandra.stamenkovic@live.com

The manuscript received: March,05, 2020.

Paper accepted: April, 24, 2020.
} 


\section{Experimental}

Bacterial strain and growth conditions

B. subtilis NCIM 2063 strain from National collection of Industrial Microorganisms (NCIM) was used to study the effect of different glucose concentrations and OTR values on the biomass yield and kinetic parameters. A bacterial strain was stored at $-80^{\circ} \mathrm{C}$ in vials and at $4{ }^{\circ} \mathrm{C}$ in agar plates. To form an inoculum, Erlenmeyer flask containing $300 \mathrm{ml}$ of Nutrient Broth (NB) was inoculated with a single colony and grown for $24 \mathrm{~h}$ in a rotary shaker at $37^{\circ} \mathrm{C}$ and $150 \mathrm{rpm}$.

This culture was then used for inoculation of $500 \mathrm{~mL} \mathrm{Er}$ lenmeyer flask containing the sterilized cultivation medium which consisted of: Nutrient Broth, $10 \%$ (w/v) KCl, $1.2 \%$ (w/v) $\mathrm{MgSO}_{4} \cdot 7 \mathrm{H}_{2} \mathrm{O}, 1 \mathrm{M} \mathrm{NaOH}, 1 \mathrm{M} \mathrm{Ca}\left(\mathrm{NO}_{3}\right)_{2}, 0.01 \mathrm{M} \mathrm{MnCl}_{2}$ and $1 \mathrm{mM} \mathrm{FeSO}_{4}$. In the first part of the experiment, four glucose concentrations and OTR values were tested $(0 \mathrm{~g} / \mathrm{L}$, $5 \mathrm{~g} / \mathrm{L}, 10 \mathrm{~g} / \mathrm{L}, 15 \mathrm{~g} / \mathrm{L})$. After that, the effect of different OTR values was evaluated $\left(10 \mathrm{~mol} / \mathrm{m}^{3} \mathrm{~h}, 5 \mathrm{~mol} / \mathrm{m}^{3} \mathrm{~h}, 4 \mathrm{~mol} / \mathrm{m}^{3} \mathrm{~h}\right.$, $2 \mathrm{~mol} / \mathrm{m}^{3} \mathrm{~h}$ ) at the constant glucose concentration (10 g/L). The shake flask cultures were grown at $150 \mathrm{rpm}$ and $37^{\circ} \mathrm{C}$, for $48 \mathrm{~h}$. The samples were taken at regular intervals for biomass and glucose determination.

\section{Biomass determination}

For dry biomass determination, $10 \mathrm{~mL}$ of the sample was centrifuged at $4000 \mathrm{rpm}$, the pellet was decanted, resuspended in $5 \mathrm{ml}$ of water, transferred to a previously measured empty glass Petri dish and dried at $105^{\circ} \mathrm{C}$ until the constant mass was achieved. Dry biomass was measured from the weight difference. The experiments were done in duplicate and the results are expressed as mean values.

\section{OTR determination}

OTR was calculated from the empirical equation for flasks shaken on orbital shakers (Equation 1) [24]:

$$
\text { OTR }=7.23 \cdot 10^{-4} \cdot\left(\frac{V_{L}}{V_{F}}\right)^{-0.845} \cdot C \cdot N .
$$

where $V_{L}$ is the liquid volume, $V_{F}$ is the flask volume, $C$ is the dissolved oxygen concentration and $N$ is the shaking speed. Since the experiments were conducted under the same conditions and the shaking speed remained constant at $150 \mathrm{rpm}$, OTR was controlled by adjusting the volume of the medium and the volume of the actual flask itself.

\section{Consumption of glucose}

In order to determine the consumption of glucose over time, the samples were taken at regular intervals in aseptic conditions for the measurement of the remaining glucose concentration. The concentration of glucose was determined spectrophotometrically, using a modified picric acid method [25]. Shortly, the samples were first centrifuged for $10 \mathrm{~min}$ at $3000 \mathrm{rpm}$, the supernatant was diluted and mixed with the picric acid solution. After 15 min of heating, the volumetric flask was filled with distilled water and the absorbance was measured at $580 \mathrm{~nm}$. The glucose concentration was determined based on a standard curve in the range of up to $15 \mathrm{~g} / \mathrm{L}$ glucose.

\section{Determination of kinetic parameters}

For each growth curve, the specific growth rate $\mu_{m}$ and generation time $t_{d}$ were calculated using the following equations [26].

$\ln \frac{x}{x_{0}}=\mu_{m} \cdot t$

$t_{d}=\frac{\ln 2}{\mu_{m}}$

where, $x$ is the biomass concentration in the moment $t$ and $x_{0}$ is the starting biomass concentration.

\section{Results and discussion}

The regulation of growth parameters is the first step in the process of obtaining the quality microbial biomass with the desired cell density. To fully understand the nutrient requirements and microorganism behavior, it is very important to analyze the growth curve and be aware of the kinetic parameters values $[27,28]$. The aim of this work was to study the microbial growth of $B$. subtilis under different cultivation conditions, particularly the glucose concentration and OTR.

A recent study showed that among various carbon sources, glucose was the most suitable carbon source for $B$. subtilis growth [29]. For that reason, glucose was chosen as the main substrate for further examination in our study.

The addition of glucose at four different concentrations was performed to increase the overall biomass, which is presented in Figure 1. After $48 \mathrm{~h}$ of cultivation, the maximum biomass yield $(6.2 \mathrm{~g} / \mathrm{L})$ was noticed in the medium containing $10 \mathrm{~g} / \mathrm{L}$ glucose, while the fastest growth was noticed in the one containing $5 \mathrm{~g} / \mathrm{L}$ glucose. The fact that glucose enhances the bacteria growth is also confirmed by the values of basic kinetics parameters given in Table 1. It can be seen that a microorganism achieved the lowest specific growth rate and the highest generation time in the medium without glucose. On the contrary, the highest specific growth rate and the lowest generation time $\left(0.329 \mathrm{~h}^{-1}\right.$ and $2.1 \mathrm{~h}$, respectively) were noticed in the medium containing $5 \mathrm{~g} / \mathrm{L}$ glucose. The consumption of glucose, on the other hand, was a relatively slow process (Figure 2). At $5 \mathrm{~g} / \mathrm{L}$, all the glucose which had been initially added to the medium was consumed after the end of the stationary phase. For higher initial concentrations there was still glucose left, even after the stationary phase.

Table 1. Kinetic parameters for the bacterial growth in the media with different glucose concentrations

\begin{tabular}{cccc}
\hline $\begin{array}{c}\text { Starting glucose } \\
\text { concentration }(\mathrm{g} / \mathrm{L})\end{array}$ & $\mu_{\mathrm{m}}\left(\mathrm{h}^{-1}\right)$ & $\mathrm{R}^{2}$ & $\mathrm{t}_{\mathrm{d}}(\mathrm{h})$ \\
\hline 0 & 0.26 & 0.857 & 2.67 \\
5 & 0.329 & 0.918 & 2.1 \\
10 & 0.282 & 0.930 & 2.46 \\
15 & 0.321 & 0.867 & 2.16 \\
\hline
\end{tabular}



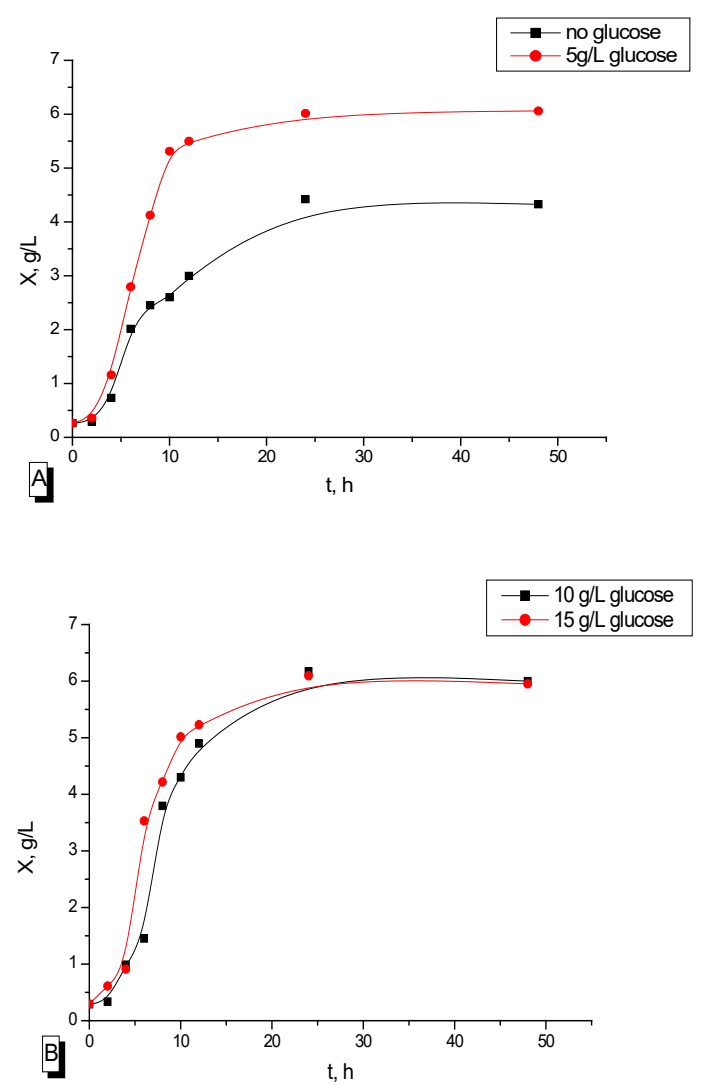

Figure 1. B. subtilis biomass $(X)$ growth over time under different glucose concentrations in the medium: $A$ : no glucose and 5 $\mathrm{g} / \mathrm{L}$ glucose; B: 10 and $15 \mathrm{~g} / \mathrm{L}$ of glucose.

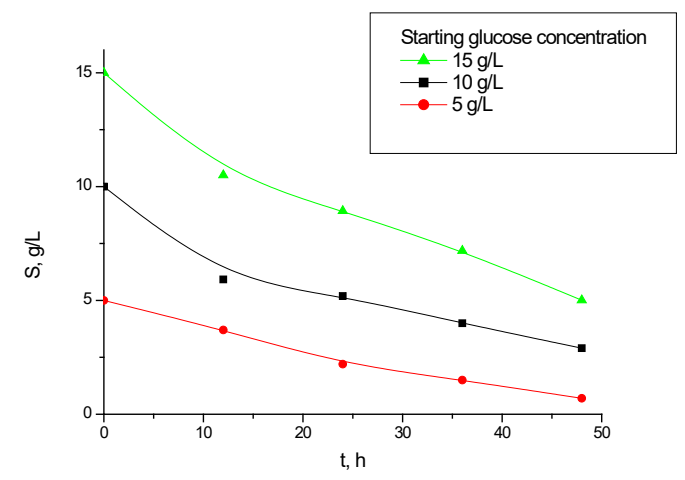

Figure 2. Consumption of glucose (S) in the media with different initial glucose concentrations

Our basic observation is that $B$. subtilis achieved a lower biomass yield when grown in the medium without glucose. When higher glucose concentrations are applied, there was no significant difference in the maximum biomass yield at the end of the cultivation period, although there were some differences in the growth rate. Another research also found that cell density increases with the increase in glucose concentration, up to $5 \mathrm{~g} / \mathrm{L}$, but remained constant at higher concentrations [30].
However, our research proves that bacterial replication occurs very fast even in the medium containing a higher concentration of glucose, which is in agreement with the study reported recently where the highest biomass yield was achieved in the medium containing $10 \mathrm{~g} / \mathrm{L}$ glucose [29]. Such results are expected because microorganisms tend to grow fast when nutrients are abundant [2]. Generally, the biomass yield achieved in this study is much higher than previously reported in a similar experiment that managed to get $0.44 \mathrm{~g} / \mathrm{L}$ biomass of $B$. subtilis UTB96 after $12 \mathrm{~h}$ of cultivation on sugar cane molasses as a carbon source [18].

During the $48 \mathrm{~h}$ of cultivation, the growth curve represented a full sigmoidal shape with three distinct phases: lag, exponential and stationary. The lag phase is very short, lasting less than two hours. The transition from exponential to stationary phase was rapid in the cases of higher glucose concentrations. A specific growth rate values ranged from $0.26-0.321 \mathrm{~h}^{-1}$ which is in agreement with the study reported previously for the batch cultivation of $B$. subtilis which grew exponentially after the lag phase with the maximum specific growth rate of $0.3 \mathrm{~h}^{-1}$ [31]. A stationary phase started approximately after $24 \mathrm{~h}$ of cultivation, which means that there is no need for fermentation to last $48 \mathrm{~h}$ and that it is economically justified to stop it earlier.

The consumption of substrate is usually monitored during fed-batch cultivations which are proven to increase the overall biomass yield [15,32]. Usually, the fed-batch process is performed to eliminate substrate inhibition and hence, achieve higher cell densities [31]. Previous studies reported that substrate inhibition of $B$. subtilis happens when the starting glucose concentration reaches $20 \mathrm{~g} / \mathrm{L}$ [30]. Our study confirms that even at $5 \mathrm{~g} / \mathrm{L}$ all the glucose is consumed after $48 \mathrm{~h}$. When higher starting glucose concentrations are applied, there is still some glucose left after fermentation. Interestingly, $B$. subtilis growth is noticed even when there is no glucose in the medium, which leads to the conclusion that the medium itself provides enough nutrients which are necessary for the metabolic processes and replication of $B$. subtilis.

Many studies have shown that oxygen plays a very important role when it comes to microbial cultivations $[20,21,33]$. It should be maintained at the constant level, since its deficiency can cause the slower microbial growth or suppress the production of desired metabolites. The concentration of dissolved oxygen in the cultivation medium depended on the value of OTR which is a key factor indicating the efficiency of aeration [33]. This study also confirms that restriction of available oxygen lowers the biomass yield of Bacillus subtilis and limits the growth of the species. When batch cultivation of $B$. subtilis was performed in shake flasks with different OTR values, and the biomass yield measured as a function of time, the results shown in Figure 3 were obtained. The highest biomass yield was achieved in a flask with the highest OTR value $\left(10 \mathrm{~mol} / \mathrm{m}^{3} \mathrm{~h}\right)$, while there was no 
significant difference in the biomass yield in the flasks where OTR values were lower than the maximum. The values of kinetic parameters under different OTR values can be seen in Table 2. The highest specific growth rate, along with the lowest generation time was observed in a flask with OTR value of $5 \mathrm{~mol} / \mathrm{m}^{3} \mathrm{~h}$, although the exponential phase lasted much shorter and the culture entered a stationary phase after about 10 hours of growth.
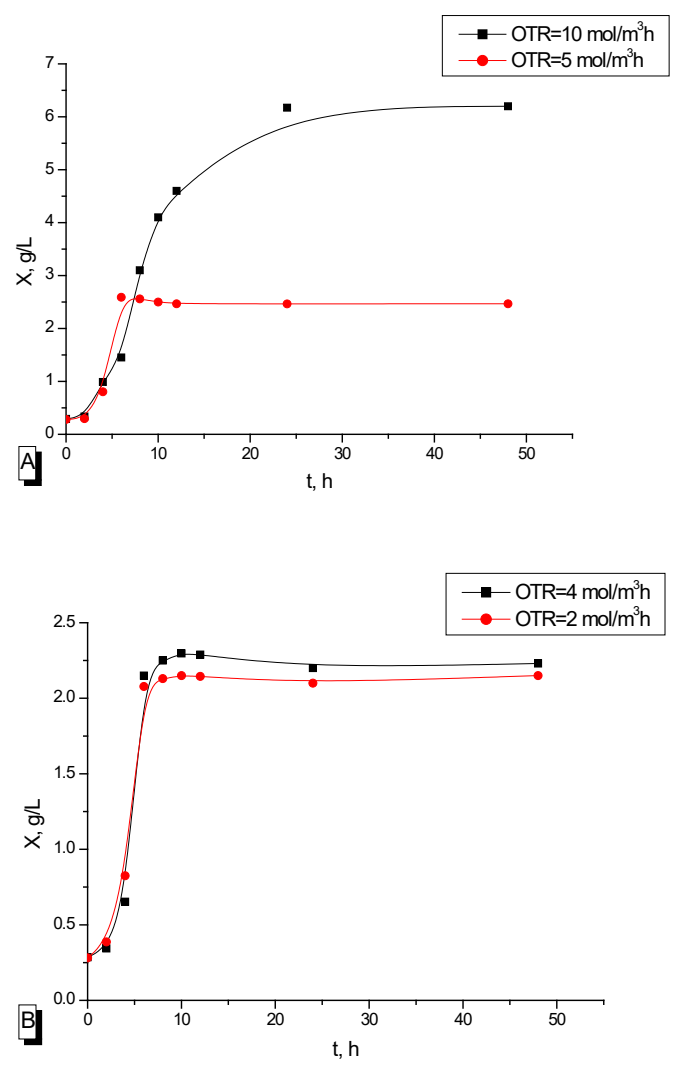

Figure 3. B. subtilis growth over time under different OTR values: A: 10 and $5 \mathrm{~mol} / \mathrm{m}^{3} \mathrm{~h}, \mathrm{~B}: 4$ and $2 \mathrm{~mol} / \mathrm{m}^{3} \mathrm{~h}$

Table 2. Kinetic parameters for the bacterial growth in the media with different OTR

\begin{tabular}{cccc}
\hline OTR $\left(\mathrm{mol} / \mathrm{m}^{3} \mathrm{~h}\right)$ & $\mu_{\mathrm{m}}\left(\mathrm{h}^{-1}\right)$ & $\mathrm{R}^{2}$ & $\mathrm{t}_{\mathrm{d}}$ \\
\hline 10 & 0.273 & 0.944 & 2.54 \\
5 & 0.293 & 0.836 & 2.365 \\
4 & 0.269 & 0.860 & 2.58 \\
2 & 0.276 & 0.897 & 2.51 \\
\hline
\end{tabular}

It leads us to the conclusion that, while the OTR value influenced the biomass yield, it did not affect the growth rates and generation times significantly. Such results indicate that, although $B$. subtilis has the ability to grow in oxygen-limited conditions relying mostly on nitrate utilization, it achieves its maximum growth under an excess of oxygen. A previous research studied the impact of the dissolved oxygen concentration on the microorganism growth and sporulation, concluding that the highest spore concentration was achieved when dissolved oxygen was above $30 \%$ of air saturation, while the sporulation efficiency was reduced under anaerobic conditions [30]. However, it would be useful if the OTR values were calculated, since OTR is a valid measure of the capacity of oxygen transfer through the vessel and a suitable criterion for the comparison of different systems and the eventual scale-up process. The importance of determining the physical parameters related to oxygen transfer was reported in the study which dealt with scale up from shake-flask to the pilot-scale production of Azospirillum brasilense, using the OTR and a volumetric mass transfer coefficient $(K\llcorner a)$ as main scale-up parameters [20]. $31 \mathrm{~h}^{-1}$ was determined as the optimum kLa value and it was the leading parameter for the adjustment of stirring speed and aeration rate, which lead to obtaining the quality product for biocontrol of pathogens [20].

\section{Conclusion}

Based on the results obtained in this research, it can be concluded that $B$. subtilis shows a rapid growth on the proposed medium even without the presence of glucose, although higher biomass yields are achieved in the medium with higher glucose concentrations. The importance of the sufficient aeration has been confirmed, since our results show that the restriction of available oxygen lowers the biomass yield. The greatest biomass yield $(6.2 \mathrm{~g} / \mathrm{L})$ was achieved in the medium with $10 \mathrm{~g} / \mathrm{L}$ of glucose and OTR value of $10 \mathrm{~mol} / \mathrm{m}^{3} \mathrm{~h}$, when a specific growth rate and generation time were $0.273 \mathrm{~h}^{-1}$ and $2.54 \mathrm{~h}$, respectively. Such biomass yield can be achieved in only $24 \mathrm{~h}$, which is also economically acceptable and recommended as optimized values for further research.

\section{Acknowledgement}

This work was financed by the Ministry of Education, Science and Technological Development of the Republic of Serbia Programme for scientific research, no: 451-0368/2020-14/200133 (Previous research project: Simultaneous Bioremediation and Soilification of Degraded Areas to Preserve Natural Resources of Biologically Active Substances, and Development and Production of Biomaterials and Dietetic Products, No: III 43004). The research was done at the Faculty of Technology, University of Niš, Bulevar Oslobođenja 124, 16000 Leskovac.

\author{
Abbreviations \\ OTR - Oxygen transfer rate \\ NB - Nutrient broth \\ kLa - Volumetric mass transfer coeficient \\ NCIM - National collection of Industrial Microorganisms
}




\section{References}

[1] M. Schallmey, A. Singh, O.P. Ward, Developments in the use of Bacillus species for industrial production, Canadian Journal of Microbiology, 50 (2004) 1-17.

[2] A.L.U. de Carvalho, F.H.P.C. de Oliveira, R. de L.R. Mariano, E.R. Gouveia, A.M. Souto-Maior, Growth, sporulation and production of bioactive compounds by Bacillus subtilis R14, Brazilian Archives of Biology and Technology, 53 (2010) 643-652.

[3] M.B. Tavares, R.D. Souza, W.B. Luiz, R.C.M. Cavalcante, C. Casaroli, E.G. Martins, R.C.C. Ferreira, L.C.S. Ferreira, Bacillus subtilis endospores at high purity and recovery yields: Optimization of growth conditions and purification method, Current Microbiology, 66 (2013) 279-285.

[4] S. Shahcheraghi, J. Ayatollahi, M. Lotfi, Applications of Bacillus subtilis as an important bacterium in medical sciences and human life, Tropical Journal of Medical Research, 18 (2015) 1-9.

[5] P. Garcia-Fraile, E. Menendez, R. Rivas, Role of bacterial biofertilizers in agriculture and forestry, AIMS Bioengineering, 2 (2015) 183-205.

[6] J. Jiang, L. Gao, X. Bie, Z. Lu, H. Liu, C. Zhang, F. Lu, $\mathrm{H}$. Zhao, Identification of novel surfactin derivatives from NRPS modification of Bacillus subtilis and its antifungal activity against Fusarium moniliforme, BMC Microbiology, 16 (2016) 31.

[7] M.S. Tanyildizi, M. Elibol, D. Özer, Optimization of growth medium for the production of a-amylase from Bacillus amyloliquefaciens using response surface methodology, Journal of Chemical Technology \& Biotechnology, 81 (2006) 618-622.

[8] J. Shafi, H. Tian, M. Ji, Bacillus species as versatile weapons for plant pathogens : a review, 2818 (2017).

[9] A. Cagri-Mehmetoglu, S. Kusakli, M. van de Venter, Production of polysaccharide and surfactin by Bacillus subtilis ATCC 6633 using rehydrated whey powder as the fermentation medium, Journal of Dairy Science, 95 (2012) 3643-9.

[10] S. Kazemi, G. Khayati, M.F. Ghasemi, Optimization of $\beta$-galactosidase production from a native Bacillus spp isolated from northern soils in Iran, Indian Journal of Biotechnology, 16 (2017) 557-562.

[11] Y. Mercado-Flores, I.O. Cárdenas-Álvarez, A.V. RojasOlvera, J.P. Pérez-Camarillo, S.G. Leyva-Mir, M.A. Anducho-Reyes, Application of Bacillus subtilis in the biological control of the phytopathogenic fungus Sporisorium reilianum, Biological Control, 76 (2014) 3640.

[12] A. Gotor-Vila, J. Usall, R. Torres, M. Abadias, N Teixidó, Formulation of the biocontrol agent Bacillus amyloliquefaciens CPA-8 using different approaches: liquid, freeze-drying and fluid-bed spray-drying, BioControl, 62 (2017) 545-555.

[13] A.M. Omer, Bioformulations of bacillus spores for using as Biofertilizer, Life Science Journal, 7 (2010) 124-131.

[14] S. Stamenković, V. Beškoski, I. Karabegović, M. Lazić, N. Nikolić, Microbial fertilizers: A comprehensive review of current findings and future perspectives, Spanish Journal of Agricultural Research, 16 (2018) e09R01.

[15] S. Stamenkovic-Stojanovic, I. Karabegovic, V. Beskoski, N. Nikolic, M. Lazic, Bacillus based microbial formulations: Optimization of the production process, Hemijska Industrija, 73 (2019) 169-182.
[16] M.H. Zweietering, I. Jonhenburger, F.M. Rombouts, K. van'T Riet, Modeling of the Bacterial Growth Curve, Applied and Environmental Microbiology, 56 (1990) 18751881.

[17] G.D. Najafpour, Biochemical engineering and biotechnology, Elsevier, Amsterdam, 2007.

[18] S. Ghasemi, M. Ahmadzadeh, Optimisation of a costeffective culture medium for the large-scale production of Bacillus subtilis UTB96, Archives of Phytopathology and Plant Protection, 46 (2013) 1552-1563.

[19] B.V. V Ratnam, M. Narasimha Rao, M. Damodar Rao, S. Subba Rao, C. Ayyanna, Optimization of fermentation conditions for the production of ethanol from sago starch using response surface methodology, World Journal of Microbiology and Biotechnology, 19 (2003) 523-526.

[20] M.A. Trujillo-Roldán, N.A. Valdez-Cruz, C.F. GonzalezMonterrubio, E. V. Acevedo-Sánchez, C. MartínezSalinas, R.I. García-Cabrera, R.A. Gamboa-Suasnavart, L.D. Marín-Palacio, J. Villegas, A. Blancas-Cabrera, Scale-up from shake flasks to pilot-scale production of the plant growth-promoting bacterium Azospirillum brasilense for preparing a liquid inoculant formulation, Applied Microbiology and Biotechnology, 97 (2013) 9665-9674.

[21] F. Garcia-Ochoa, E. Gomez, Bioreactor scale-up and oxygen transfer rate in microbial processes: An overview, Biotechnology Advances, 27 (2009) 153-176.

[22] A.-I. Galaction, C. Oniscu, D. Cascaval, Studies on oxygen mass transfer in stirred bioreactors 2: Suspensions of bacteria, yeasts and fungis, Hemijska Industrija, 57 (2003) 276-287.

[23] W. Klockner, J. Buchs, Advances in shaking technologies, Trends in Biotechnology, 30 (2012) 307-314.

[24] V.B. Veljković, S. Nikolić, M.L. Lazić, C.R. Engler, Oxygen transfer in flasks shaken on orbital shakers, Hemijska Industrija, 49 (1995) 265-272.

[25] J.J. Willaman, F.R. Davison, Some modifications of the picric acid method for sugars, Journal of Agricultural Research, 28 (1924) 479-487.

[26] V.B. Veljković, Osnovi biohemijskog inženjerstva, Univerzitet u Nišu. Tehnološki fakultet u Leskovcu, Leskovac, 1994.

[27] G. Sreekumar, S. Krishnan, Enhanced biomass production study on probiotic Bacillus subtilis SK09 by medium optimization using response surface methodology, African Journal of Biotechnology, 9 (2010) 8078-8084.

[28] S.M.S. Monteiro, J.J. Clemente, M.J.T. Carrondo, A.E. Cunha, Enhanced Spore Production of Bacillus subtilis Grown in a Chemically Defined Medium, Advances in Microbiology, 4 (2014) 444-454.

[29] N.N. Ngoc, N. Van Cach, T.D. Giap, Optimization of fermentation conditions for collecting of Bacillus subtilis NT1 biomass used in Canna Edulis Ker processing wastwater treatment, Biotechnology and Seedling, 2 (2017) 3-8.

[30] S.M. Monteiro, J.J. Clemente, A.O. Henriques, R.J. Gomes, M.J. Carrondo, A.E. Cunha, A procedure for highyield spore production by Bacillus subtilis, Biotechnology Progress, 21 (2005) 1026-1031.

[31] S.M. Matar, S.A. El-Kazzaz, E.E. Wagih, A.I. El-Diwany, H.E. Moustafa, M.A. El-Saadani, G.A. Abo-Zaid, E.E. Hafez, Bioprocessing and scaling-up cultivation of Bacillus subtilis as a potential antagonist to certain plant pathogenic fungi, III, Biotechnology, 8 (2009) 138-143.

[32] R. Davis, G. Duane, S.T. Kenny, F. Cerrone, M.W. Guzik, 
R.P. Babu, E. Casey, K.E. O'Connor, High cell density cultivation of Pseudomonas putida KT2440 using glucose without the need for oxygen enriched air supply, Biotechnology and Bioengineering, 112 (2015) 725-733.

[33] F. Garcia-Ochoa, E. Gomez, V.E. Santos, J.C. Merchuk, Oxygen uptake rate in microbial processes: An overview, Biochemical Engineering Journal, 49 (2010) 289-307.

\section{Izvod \\ ŠARŽNA KULTIVACIJA BACILLUS SUBTILIS NCIM2063: UTICAJ KONCENTRACIJE SUPSTRATA I PRENOSA MASE KISEONIKA NA PRINOS BIOMASE}

Sandra Stamenković Stojanović ${ }^{1}$, Ivana Karabegović ${ }^{1}$, Vladimir Beškoski², Nada Nikolić ${ }^{1}$, Miodrag Lazić ${ }^{1}$

(ORIGINALNI NAUČNI RAD) UDK 602.3:579.6

${ }^{1}$ Tehnološki fakultet, Leskovac, Univerzitet u Nišu, Srbija

2Hemijski fakultet, Beograd, Univerzitet u Beogradu, Srbija

U radu je opisana kinetika rasta vrste Bacillus subtilis NCIM 2063 koja je gajena u erlenmajerima sa mešanjem na podlozi sa različitim koncentracijama glukoze i vrednostima koeficijenta prenosa mase kiseonika (eng. oxygen transfer rate OTR). Kultivacioni uslovi i sastav hranljive podloge su uticali na prinos biomase, specifičnu brzinu rasta i generacijsko vreme. Potvrđeno je da je glukoza lako dostupan supstrat koji pozitivno utiče na kultivaciju $B$. subtilis pri koncentracijama u opsegu 5-15 g/L. Takođe, dokazano je da restrikcija dostupnog kiseonika smanjuje prinos biomase i usporava umnožavanje bakterija. Maksimalni prinos biomase postignut je u podlozi za $10 \mathrm{~g} / \mathrm{L}$ glukoze i pri vrednosti OTR od $10 \mathrm{~mol} / \mathrm{m} 3 \mathrm{~h}$, kada su specifična brzina rasta i generacijsko vreme bili $0.273 \mathrm{~h}^{-1}$ i $2.54 \mathrm{~h}$, respektivno. Pomenuti prinos biomase ostvaren je za samo $24 \mathrm{~h}$ što je izuzetno poželjno sa ekonomske tačke gledišta. Stoga, uslovi rasta optimizovani ovim istraživanjem mogu se koristiti za ekonomičnu i efikasnu kultivaciju B. subtilis NCIM 2063.
Ključne reči: mikrobna biomasa, Bacillus subtilis, kinetika rasta 